高分子化学 (Kobunshi Kagaku), Vol. 30, No. 341, pp. 535--541 (Sept., 1973)

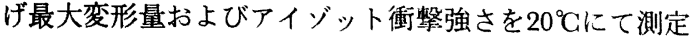
し，その結果を Table 1 および Fig. 3 に示した。

大変形試験である曲げ強さでは, 液状ポリブタジェン ブレンドの場合，その量とともに強さが低下し，分子量 が大きいほど低下が大きい。柔軟性樹脂ブレンドの場合 もその低下の程度は小さいがかなり低下する。曲げ最大 変形量は両ブレンド系ともに10部まではほとんど変わら ず，20部の添加でかなり大きくなり，同じ傾向を示し， 微小変形試験である動的粘弾性の挙動がかなり相違した にもかかわらず，機械的性質にはあまり反映しなかっ た。

衝撃強さはノッチ効果を考慮して，ノッチ付き，ノッ チなしのアイジット衝撃強さを測定した。曲げ変形量の 增大およびゴムブレンドポリスチレンの例よりかなりの 向上が期待されたが，両ブレンド系ともに無添加樹脂と ほほ同じかやや小さいものしか得られなかった。これは ブレンドにより変形量は増すが，同時に強さが低下する こと, 液状ポリブタジェンのエポキシ樹脂への溶解性が 小さすぎること ${ }^{2)}$, 柔軟性樹脂では溶解性が大きすぎる ことなどが原因と考えられる。

\section{4. まとめ}

1. 剛直な橋かけ高分子であるエポキシ樹脂に柔軟な 鎖をもつポリマーを導入すると，液状ポリブタジェンで は $T_{g}$ は変化せず, ガラス領域の $E^{\prime}$ が低下する典型的 な 2 相系の動的粘弾性を示した。柔軟性樹脂では $T_{g}$ が 低下し，転移領域が広がり，可塑化されることがわかっ た。

2. 機械的性質はこれらの構造の違いを反映せず，と もに同じように強さが低下し，伸びが増して柔軟性が増 した。

3. 液状ポリブタジェンブレンドにより，所期の目的
である耐衝撃性は改善されなかったが，耐熱性 $\left(T_{g}\right)$ を 低下させることなく，柔軟性が与えられることがわかっ た。

付記本研究の試料の一部を提供していただいた日本 曹達株式会社に哚く感謝します。本稿の一部は第22回熱 硬化性樹脂（3 次元高分子）講演討論会（昭和47年10月, 大阪）にて発表した。

\section{文献}

1) たとえば, H. Lee, K. Neville: "Handbook of Epoxy Resins", McGraw-Hill Book Co. (1967), pp. 16-1 32; 垣内 弘: “エポキシ樹脂”, 昭晃 堂 (1970), pp. 153 156

2) E. H. Rowe, A. R. Siebert, R. S. Drake: Mod. Plast., 110 (Aug., 1970)

3) A. C. Soldatos, A. S. Burhans: Ind. Eng. Chem. Prod. Res. Develop., 9, [3], 296 (1970)

4) T. K. Kwei: J. Polym. Sci. A-2, 4, 417 (1966)

5）小菅詔雄, 矢野彰一郎, 金丸 競: 高分子化 学, 28, 719 (1971)

6）深沢康俊，田中基喜，和田英一：第21回熱硬 化性樹脂討論講演会要旨集, 38A (1971)

7) 端 直明, 吉田 慧, 山内 亮, 熊野奚谷 従: 第 21 回熱硬化性樹脂討論講演 会 要旨集, 43A (1971)

8) 端 直明, 山内 亮, 熊野谿 従：第22回熱 硬化性樹脂討論講演会要旨集, 19A (1972)

9) L. E. Nielsen (小野木訳)：“高分子の力学的 性質”, 化学同人 (1969), p. 131

10）後藤廉平，平井西夫，花井哲也：“レオロジー とその応用”，共立出版 (1962), p. 4

11) L. E. Nielsen (小野木訳)：“高分子の力学的 性質”, 化学同人 (1969), pp. 162 164

\title{
ポリエチレンに対する塩化ビニル一酢酸ビニルの 放射線共グラフト反応
}

(受付1973年1月 4 日・掲載決定1973年 5 月18日)

貴家恒男*1 ・清水雄一 ${ }^{* 1} \cdot$ 佐々木 隆*1 王置 寛*1 ・荒木邦夫*1

要 旨 電子線前照射法によるポリエチレン $(\mathrm{PE})$ 一の塩化ビニル $(\mathrm{Vc})$ 一酢酸ビニル $(\mathrm{VAc})$ の共 グラフト重合における反応した PE の割合 (RPE) および真のグラフト㳯 $\left(G_{n}\right)$ に対する反応条件の

*1 日本原子力研究所高崎研究所 ( $\overline{\mathbf{T}} 370$-12 高崎市綿貫町 1233) 
影響を検討した。 $\mathrm{RPE}, G_{n}$ はVcが多いほど，また反応温度が高いほど反応初期に急速に增加す る。メタノールを添加しても RPEの経時変化に影響はないが， $G_{n}$ は著しく減少した。 RPEの飽 和化（2 時間以上, 約 $30 \%$ ) したのちにも $\mathrm{G}_{n}$ が増加することから，本報告におけるグラフト重合 の反応は停止の機会の少ない反応と推定した。また，バルク系ではグラフト鎖中のモノマー組成比 は，一般のラジカル重合における MRRから求めたものと良い一致を示した。

\section{1. 緒言}

著者らはポリエチレンの機械的強度を改良する目的 で, 塩化ビニル (Vc) と酢酸ビニル (VAc) を電子線前照 射法で，ポリエチレンにグラフトする研究を行なってき た。この研究を通じて, 反応温度や反応溶媒の有無など の反応条件が変わると, 同じ平均グラフト率でも, 降伏 点強度, アイゾット衝撃強度などの機械的強度に差が生 じることが認められた。これらの機械的強度の差は，グ ラフトポリエチレンの組成とグラフト鎖の化学構造が異 なることに起因するものであると推定される。

グラフトポリエチレンの機械的強度に関する研究は,

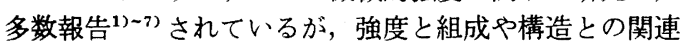
性については明らかにされていない。これは，セルロー スや PVA を幹ポリマーとした場合のように加水分解に よって構造を明らかにする ${ }^{8,9)}$ という手法が，ポリエチ レンの場合には適用できないことによる。そこで著者ら は，溶媒抽出法により，Vc-VAc 共グラフトポリエチ レンについて, 反応しているポリエチレンと末反応ポリ エチレンの分離を行なった。本報では, 反応したポリエ チレン量および反応した幹1 本あたりのグラフト率に対 する反応条件の影響について報告する。

\section{2. グラフト率などの定義}

一般にグラフト重合体には, 内部重合ホモポリマーが 含まれている。本研究では, 次章で述べる操作によって 内部重合ホモポリマーを分離し，このときの仕込み幹ポ リマーに対する重量増加率を「平均グラフト率 $\left.G_{a}{ }^{* 11}\right\rfloor$ とする。

$$
G_{a}=\frac{\text { 枝ポリマーの重量 }}{\text { 仕込み } \mathrm{PE} \text { の全重量 }} \times 100
$$

また，仕込みポリエチレン分子がすべてグラフトされ るのではなく，多くのポリエチレン分子が末反応のまま 残っている。この未反応のポリエチレン分子を除いて得 られたものは幹と枝が化学的に結合したポリマーであ り，「純粋のグラフト重合体」と呼ぶ。また，そのとき のグラフト率を「純粋のグラフト率 $\left(G_{n}\right.$, Net Percent Graft)」と呼ぶことにする。 $G_{n}$ は (2)式で示される。

$$
G_{n}=\frac{\text { 枝ポリマー重量 }}{\text { 反応に使われた PE の重量 }} \times 100
$$

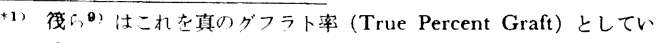
¿。
反応に使われたポリエチレン量の仕込みポリエチレン に対する重量百分率 (RPE) は (1)，(2) 式から(3)式のよ うに計算される。

$$
\mathrm{RPE}=\frac{G_{a}}{G_{n}} \times 100
$$

\section{3. 実験}

\section{1 試料およびグラト重合}

ポリエチレンは酸化防止剂などの添加物をまったく含 まないHizex 1200P 粉末 (三井石油化学, 密度 : 0.943g /cc, $\tilde{M}_{n}: 3.5 \times 10^{4}$ ，メチル分岐数 $29 / 1000 \mathrm{CH}_{2}$ ) をその まま使った。モノマーの塩化ビニル (Vc) と酢酸ビニル (VAc) は常法で精製したのち使った。なお Vc と VAc モノマーの $20^{\circ} \mathrm{C}$ での密度はいずれも $0.94 \mathrm{~g} / \mathrm{cc}$ であるの で， vol\% と wt \% は同じである。反応溶媒として使っ たメタノールは市販特級品をそのまま使用した。

グラフト重合はすべて電子線前照射法によった。ポリ エチレン試料はドライアイスで $-78^{\circ} \mathrm{C}$ に予泠し, 照射中 この温度に保つためにドライアイス上で $3 \mathrm{Mrad}(2 \mathrm{MeV}$, $1 \mathrm{~mA}$ ) 空気中で照射を行なった。反応開始までドライア イス中に保存した。グラフト反応系としては大別して, まったく反応溶媒を含まない「Bulk 系グラフト」とメタ ノールを反応系に加えた「メタノール溶液系グラフト」 の 2 種の反応系で行ない比較した。

いずれの場合も照射したポリエチレンをSUS-27製才 ートクレーブ中に移し $10^{-2} \mathrm{mmHg}$ で10分間脱気したの ち, モノマーおよびメ夕ノールを加え, かきまぜながら $0^{\circ} \mathrm{C}, 20^{\circ} \mathrm{C}, 30^{\circ} \mathrm{C}$ で所定時間反応させた。反応終了後は全 重合物をメタノールで沈殿させた。なおモノマーは大過 剩（重量にして約 3.3 倍）使った。

\section{2 分離と定}

上記の方法で得られたポリマー中には, ポリマー表面 および内部で重合したホモポリマー，真に化学的にグラ フトした純粋のグラフトポリマーおよび末反応のまま残 っている末反応ポリエチレンが存在する。これらの分離 は以下の溶媒抽出法によった。

全重合物をテトラヒドロフラン (THF) に室温で24時 間浸せきし,表面のホモポリマーを除いた。さらにグラフ ト重合体を $10 \%$ のジメチルホルムアミド (DMF) を含む キシレンに $100^{\circ} \mathrm{C}$ で完全に溶解したのち，室温にもどす 操作で内部重合ホモポリマーを溶液中に残してロ過する ことにより取り除いた。ホモポリマーが完全に除かれた 
と考えられるこのグラフト重合体を「平均のグラフト重 合体」と呼ふ。

この「平均のグラフト重合体」中には純粋のグラフト ポリエチレンと末反応のまま残っている未反応ポリエチ レンが存在する。未反応のポリエチレンを取り除く操作 はnーヘプタンとキシレンの混合溶媒を使って行なった。 「平均のグラフト重合体」を 150 mesh の金鎆に入れ，50 〜 $75 \mathrm{vol} \%$ の $n$-ヘプタンと $25 \sim 50 \%$ のキシレン混合物 の濐度を順次 5 段階に分けて変え， $100^{\circ} \mathrm{C}$ でもはや末反 応ポリエチレンが抽出されなくなるまで綝り返し抽出し た。実験的には 3 回の抽出により成分の変化が認められ なかったので，このなかには未反応のポリエチレンは存 在しないと考えられる。したがって，この抽出されずに 残ったポリマーを「純粋のグラフト重合体」とみなし た。

平均のグラフト重合体および純粋のグラフト重合体の それぞれのグラフト率を平均のグラフト率および純粋の
グラフト率とし，これらは炭素および塩素の元素（柳本， C. $\mathrm{H} . \mathrm{Cl}$ コーダー）分析値から求めた。

\section{4. 実験結果}

反応条件㧍よび平均グラフト率 $\left(G_{a}\right)$, 純粋のグラフト 率 $\left(G_{n}\right)$, 反応に使われたポリエチレンの割合 (RPE), グ ラフト鎖中の Vc成分量をまとめて Table 1 に示す。

\section{1 モノマー組成の影留}

バルク系で反応温度一定 $\left(20^{\circ} \mathrm{C}\right)$ とし，仕込みのモ） マー組成を変化させたときの， $G_{n}$ および RPE と反応時 間との関係をそれぞれ Fig. 1, Fig. 2 に示す。Fig. 1 で は, $\mathrm{Vc}$ 成分が多いほど, 反応初期の $G_{n}$ の増加は著し い。またどのモノマー組成の場合も反応時間の経過とと もに $G_{n}$ の増加速度は次第に小さくなる。 RPE は反応時 間が同じ場合には，Vc成分の多いほど大きいが，比較 的短時間で一定值に達する傾向がある。その到達值はた かだか30\%程度である (Fig. 2)。また RPE 值が飽和後

Table 1. Reaction condition and results of grafting.

\begin{tabular}{|c|c|c|c|c|c|c|c|c|}
\hline No. & $\begin{array}{l}\text { Time } \\
(\min )\end{array}$ & $\begin{array}{l}\text { Temp. } \\
\left({ }^{\circ} \mathrm{C}\right)\end{array}$ & $\begin{array}{c}\text { Vc/VAc } \\
\text { in monomer } \\
\text { (vol ratio) }\end{array}$ & $G_{a^{\mathrm{a}}}$ & $\left.G_{n} \mathrm{~b}\right)$ & $\mathrm{RPE}^{\mathrm{c})}$ & $\begin{array}{l}\mathrm{Vc} w \mathrm{w} \% \\
\text { in graft chain }\end{array}$ & $\begin{array}{l}\text { Vc wt } \% \\
\text { calcd. } r, r_{2}{ }^{10)}\end{array}$ \\
\hline $8-1$ & 15 & \multirow[t]{3}{*}{20} & \multirow[t]{3}{*}{$92.5 / 7.5$} & 16.5 & 89.5 & 18.4 & 91.7 & \multirow[t]{3}{*}{92.0} \\
\hline $8-2$ & 25 & & & 19.5 & 92.6 & 21.1 & 91.5 & \\
\hline $8-3$ & 35 & & & 23.3 & 101.8 & 22.9 & 91.8 & \\
\hline $25-1$ & 90 & \multirow[t]{3}{*}{0} & \multirow[t]{3}{*}{$75 / 25$} & 9.7 & 46.9 & 19.6 & 84.7 & \\
\hline $25-2$ & 180 & & & 23.0 & 78.3 & 29.4 & 83.7 & \\
\hline $25-3$ & 300 & & & 28. 2 & 86.5 & 32.6 & 84.8 & \\
\hline $25-4$ & 15 & \multirow[t]{4}{*}{20} & \multirow[t]{4}{*}{$75 / 25$} & 5.4 & 69.6 & 6.3 & 84.1 & \multirow[t]{4}{*}{84.3} \\
\hline $25-5$ & 30 & & & 15.7 & 92.4 & 13.0 & 82.3 & \\
\hline $25-6$ & 75 & & & 40.4 & 147.8 & 27.5 & 83.6 & \\
\hline $25-7$ & 150 & & & 48.4 & 164.5 & 29.5 & 84.0 & \\
\hline $25-8$ & 11 & \multirow[t]{3}{*}{30} & \multirow[t]{3}{*}{$75 / 25$} & 10.9 & 74.5 & 15.8 & 88.2 & \\
\hline $25-9$ & 30 & & & 22.3 & 84.5 & 26.1 & 84.0 & \\
\hline $25-10$ & 60 & & & 23.4 & 86.7 & 26.9 & 83.1 & \\
\hline $38-1$ & 480 & 30 & $63 / 37$ & 46.5 & 141.0 & 33.0 & 75.7 & 77.3 \\
\hline $50-1$ & 120 & \multirow[t]{3}{*}{20} & \multirow[t]{3}{*}{$50 / 50$} & 18.9 & 82.8 & 22.8 & 70.7 & \multirow[t]{3}{*}{70.4} \\
\hline $50-2$ & 180 & & & 25.4 & 103.1 & 24.6 & 70.9 & \\
\hline $50-3$ & 960 & & & 32.3 & 120.0 & 26.9 & 71.0 & \\
\hline M-1* & 60 & \multirow[t]{4}{*}{20} & \multirow[t]{4}{*}{$75 / 25$} & 6.3 & 24.8 & 25.3 & 85.0 & \multirow[t]{4}{*}{84.3} \\
\hline M-2 & 120 & & & 7.6 & 25.9 & 29.5 & 80.6 & \\
\hline $\mathbf{M}-3$ & 300 & & & 11.7 & 38.5 & 30.4 & 82.1 & \\
\hline$M-4$ & 1020 & & & 22.0 & 58.5 & 37.1 & 82. 0 & \\
\hline
\end{tabular}

a) Average percent graft, b) Net percent graft, c) wt $\%$ of reacted polyethylene

* Methanol graft system with $75 \%$ of methanol 


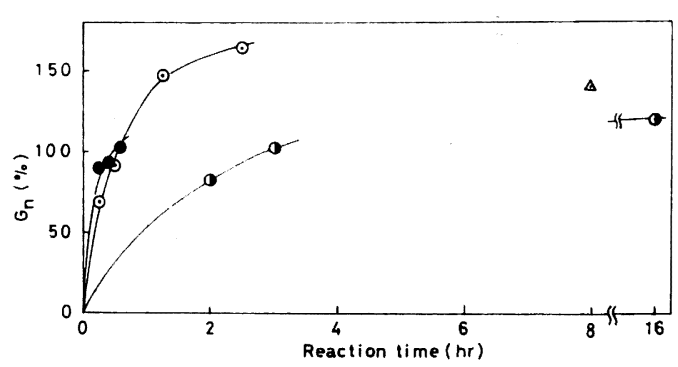

: $92.5 \%$ of $\mathrm{Vc}, 7.5 \%$ of VAc, $\bigcirc: 75 \%$ of Vc, $25 \%$ of VAc, $\triangle: 63.0 \%$ of Vc, $37.0 \%$ of VAc, (1) $50 \%$ of $\mathrm{Vc}, 50 \%$ of VAc

Fig. 1. Effect of monomer component on net percent graft $\left(G_{n}\right)$ in bulk graft system at $20^{\circ} \mathrm{C}$.

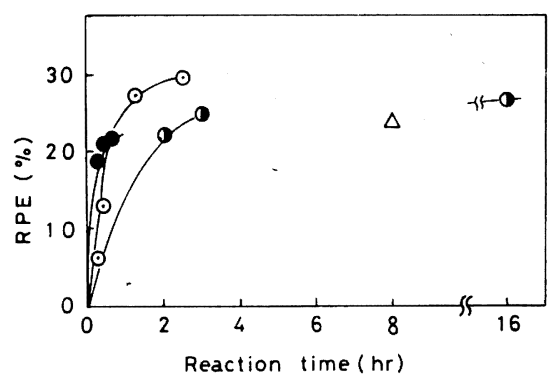

: $92.5 \%$ of Vc, $7.5 \%$ of VAc, $0: 75 \%$ of Vc, $25 \%$ of VAc, $\triangle: 63.0 \%$ of Vc, $37.0 \%$ of VAc,

- $50 \%$ of $\mathrm{Vc}, 50 \%$ of VAc

Fig. 2. Effect of monomer component on reacted polyethylene (RPE) in bulk graft system at $20^{\circ} \mathrm{C}$.

も $G_{n}$ は増加する傾向が見られる。

つぎに Table 1 に示したように，グラフト物の元素分 析の結果から求めたグラフト鎖中の Vc 成分は, VcVAc ラジカル共重合におけるモノマー相対反応性比の

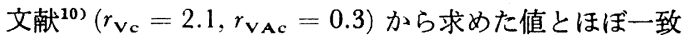
している。この結果から，このグラフト系における共重 合性は, 通常のラジカル重合における共重合性とよく一 致していることがわかる。

\section{2 反応温度の影敕}

バルク采で，仕込みモノマー比を一定 (Vc/VAc $=75$ $125 \mathrm{vol}$ 比）とし, 反応温度を $0^{\circ} \mathrm{C}, 20^{\circ} \mathrm{C}, 30^{\circ} \mathrm{C}$ と変化さ せたときの $G_{n}$ と RPE の経時変化を Fig. 3, Fig. 4 に示 す。低温 $\left(0^{\circ} \mathrm{C}\right)$ では, 初期の $G_{n}$ の増加速度は小さいが, 長時間にわたって $G_{n}$ は増加している。 $20^{\circ} \mathrm{C}$ の反応で は, $0^{\circ} \mathrm{C}$ の反応に比較して, 初期の $G_{n}$ の増加速度は大 きいが，より短時間で飽和寸る傾向が見られる。 $30^{\circ} \mathrm{C} の$ 反応では, この傾向はさらに強くなり, 初期の $G_{n}$ の増
加はきわめて大きいが，反応は 1 時間程度で実際上終了 してしまう。

RPE は低温では，その初期における増加速度は小さ いが，長時間反応を続ける。

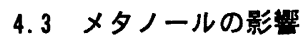

反応温度 $20{ }^{\circ} \mathrm{G}$ にけるバルク系と $75 \%$ のメタノールを 系に加えたメタノール溶液系の場合の RPE 值の経時変 化を比較して Fig. 5 に示す。バルク系とメタノール溶液 系では RPE についての差は認められない。しかし， Table 1 に示すように, $G_{a}, G_{n}$ ともバルク系の約 $1 / 5$ 程度 の值となる。

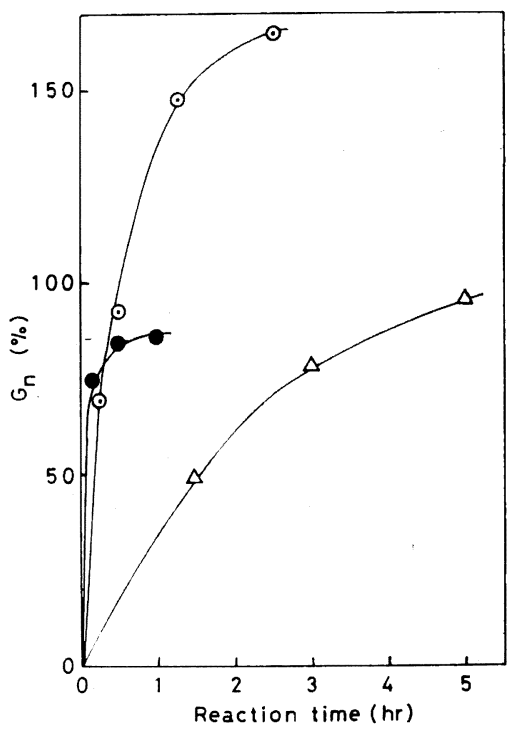

$\triangle: 0^{\circ} \mathrm{C}, \bigcirc: 20^{\circ} \mathrm{C}, \bigcirc: 30^{\circ} \mathrm{C}$

Fig. 3. Effect of reaction temperature on net percent graft $\left(G_{n}\right)$ in bulk graft system with $75 \%$ of $\mathrm{Vc}$ and $25 \%$ of VAc.

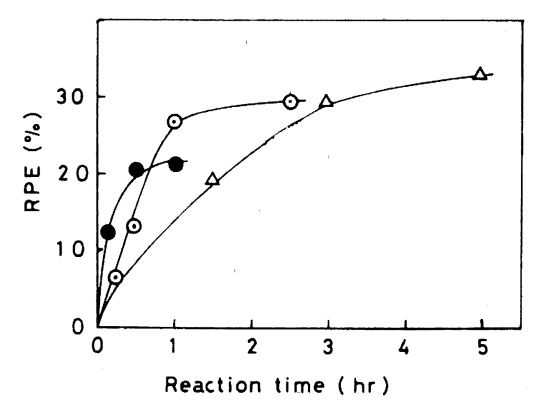

$$
\triangle: 0^{\circ} \mathrm{C}, \odot: 20^{\circ} \mathrm{C}, \bigcirc: 30^{\circ} \mathrm{C}
$$

Fig. 4. Effect of reaction temperature on reacted polyethylene (RPE) in bulk graft system with $75 \%$ of $\mathrm{Vc}$ and $25 \%$ of VAc.

高分子化学, Vol. 30, No. 341 (Sept., 1973) 
ポリエチレンに対する塩化ビニル一酶酸ビニルの放射線共グラフト反応

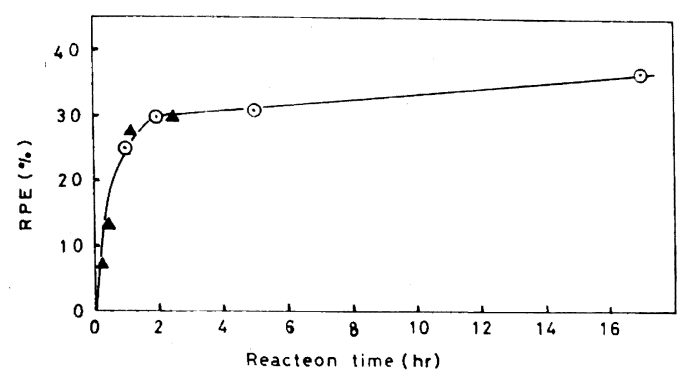

A : Bulk graft system, $\odot:$ Methanol graft system with $75 \%$ of methanol

Fig. 5. Effect of methanol on reacted polyethylene (RPE) at $20^{\circ} \mathrm{C}$ with $75 \%$ of $\mathrm{Vc}$ and $25 \%$ of VAc.

つぎにグラフト鎖におけるモノマー単位組成の分析結 果は, メタノール溶液系では $r_{\mathrm{Ve}}, r_{\mathrm{VAc}}$ から計算した值 よりVc 成分がやや多い傾向が見られる。

\section{5. 考察}

\section{1 反応に関与するポリエチレン分子数}

本実験で求めた RPE 值から，グラフト反応に関与し た PE 分子数は下記のように求められる。

ハイゼックス $1200 \mathrm{P}$ の数平均分子量 $\left(\tilde{M}_{n}\right)$ は $3.5 \times$ $10^{4}$ であるから，PE $1 \mathrm{~g}$ あたりの分子数 $N$ は

$$
N=\frac{6.0 \times 10^{23}}{3.5 \times 10^{4}}=1.7 \times 10^{19}
$$

RPE 值は，いずれの実験条件においてもほほ $30 \%$ 以 下であるので，枝の生じた $\mathrm{PE}$ 分子数 $N^{\prime}$ は，

$$
N^{\prime} \leqq 1.7 \times 10^{19} \times 0.3 \approx 5 \times 10^{18} \quad(\text { 個 } / \mathrm{g})
$$

となる。

この值を用いて，グラフト重合の開始の $G$ 值 $\left(G_{b}\right)$ を 次式により計算することができる。

$$
G_{b}=\frac{N \times 100}{D \times A}
$$

ただし， $D$ は照射線量 $(\mathrm{rad}) ， A$ はエネルギー換算係 数 $\left(5.8 \times 10^{13} \mathrm{eV} \cdot \mathrm{rad}^{-1} \cdot \mathrm{g}^{-1}\right)$ である。 $N^{\prime}=5 \times 10^{18} \cdot \mathrm{g}^{-1}$, $D=3 \times 10^{6} \mathrm{rad}$ を代入すると， $G_{b} \doteqdot 3$ となる。

ESR 法あるいは水素発生量から求めた PE ラジカル の生成の $G$ 値 $\left(G_{R}\right)$ として 2.5 6.4 が報告 ${ }^{11)}$ されてい る。本報告で求めた $G_{b}$ 值 $(\doteqdot 3)$ は $G_{R}$ の文献值とほぼ 一致しており，照射によって生成した PE ラジカルが本 系のグラフト反応の開始点としてきわめて有効に使用さ れていることを示している。

\section{2 グラフト鎖の生長反応}

純粋のグラフト率 $G_{n}$ は (2) 式の定義から(4)式のよう に書き換えられる。

$$
\begin{aligned}
G_{n} & =\frac{\text { グラフト鎖の重量 }}{\text { 反応に使われた PE } の \text { 重量 }} \times 100 \\
& =\frac{\text { グラフト鎖の平均分子量 } \times \text { 鎖数 }}{\tilde{M}_{n}(\mathrm{PE}) \times \text { 反応した } \mathrm{PE} \text { 分子数 }\left(N^{\prime}\right)}
\end{aligned}
$$

すなわち，グラフト鎖の平均分子量 $\tilde{M}_{n}(G)$ は (5) 式で 求められる。

$$
\tilde{M}(G)=\frac{G_{n} \times \tilde{M}_{n}(\mathrm{PE}) \times N^{\prime}}{ク^{\prime} \text { ラフ鎖数 } \times 100}
$$

また前述のようにポリエチレンのラジカルの生成の $G$ 值は 2.5 6.4であり ${ }^{11)}$ ，この値から， $3 \mathrm{Mrad}$ 照射して 生成するラジカル数を計算すると, $4 \sim 11 \times 10^{18}$ 個 $/ \mathrm{g}(\mathrm{PE})$ となる。本実験に用いたポリエチレンの数平均分子量 (3. $\left.5 \times 10^{4}\right)$ を考慮すると, $3 \mathrm{Mrad}$ 照射では 4 1.6本の ポリエチレン分子あたり1個の割合でラジカルが生成す ることになる。したがって，ポリエ.チレン 1 分子あたり 2 個以上のラジカルが生成する確率は少ないと考えられ る。他方生長鎖ラジカルがポリエチレンに連鎖移動し, グラフト鎖数を増加させる可能性がある。しかし PVA， ナイロン，ポリエチレンテレフタレート，七ルロースな どの幹ポリマー 1 分子あたりの枝の平均本数は 1 本であ

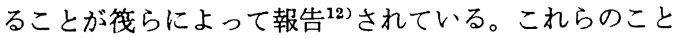
から，反応したポリエチレン１分子あたり１本の枝をも つと考えるのは至当である。

この仮定に立つと，(5) 式において，(グラフト鎖数） $=N^{\prime}$ となり，(6)式が導かれる。

$$
\tilde{M}_{n}(G)=\frac{G_{n} \times \tilde{M}_{n}(\mathrm{PE})}{100}=G_{n} \times 3.5 \times 10^{2}
$$

すなわち, $G_{n}$ はグラフト鎖の平均分子量と正比例す るので， $G_{n}$ をもってグラフト鎖の平均分子量を論ずる ことができる。

Fig. 1, Fig. 4 に見られるように， $G_{n}$ は反応初期に著 しく増大し，その後も反応時間とともに増加し続ける。 このことは (6) 式を考虑すると, 反応初期にグラフト鎖 の平均分子量が著しく増大し，そののちも反応時間とと もに増加していくと言い換えることができる。この実験 事実は，グラフト反応が一般の開始と停止によるラジカ ル濃度に関する定常状態が保たれる重合と異なり，生長 反応がきわめて制約されたマトリックス中で起こること を示している。すなわち，マトリックス中の反応である ため，生長鎖ラジカルの再結合による停止の機会が少な い反応と考えられる。RPE 值が飽和したのちにも, $G_{n} か ゙$ 増加する傾向が認められること (Fig. 1 と 2, Fig. 4, 5) も停止の機会の少ない反応であることを示している。

反応時間とともに RPE 值が増加する現象は，つぎの 知見によって理解される。i) グラフト反応はモノマーが 接近しやすいポリエチレンの非晶部と結晶部の境界領域 で起こる ${ }^{13)}$ 。ii) 結晶内部に凍結されたラジカルは反応 
時間の経過につれてマイグレーションにより境界領城で グラフト反応に関与するようになる ${ }^{14)}$ 。初期の RPE 増 加は主としてi）により，後期では主としてii)によると 考えられる。

反応温度が高い場合に RPE 值の飽和化が速く, $30^{\circ} \mathrm{C}$ の反応で飽和值が小さいことはマイグレーションとラジ カルの再結合の温度依存性に関係すると考えられる。

バルク系とメタノール溶液系を比較すると, RPEの 経時変化には差が認められない(Fig. 5)。しかし, Table 1 に示すように, メタノール溶液系の $G_{n}$ は非常に小さ い。この理由として, メタノールによるモノマーの希釈 効果と生長鎖末端ラジカルの溶媒への連鎖移動が考えら れる。一方, 生長鎖末端ラジカルのポリエチレンへの連 鎖移動も考えられるが， RPE 值の経時変化に両系で差 が認められないことから, とくにメタノール溶液系でこ の程度の連鎖移動が起こっているとは考えられない。

\section{3 グラフト鎖のモノマー単位組成比}

バルク系の反応では，グラフト鎖のモノマー単位組成 比は，モノマー仕込み比と通常のラジカル重合における MRR 值からの計算值とほぼ一致している。著者らは, PE に対するスチレンーブタジェン，あるいはスチレン 一アクリル酸エチルの共グラフト重合を行ない, これら の系でもモノマーの相詨反応性に関しては, 通常のラジ カル共重合の場合と差異がないことを示した ${ }^{15)}$ 。また, Odian らは，各種の系の共グラフト重合におけるモノマ 一反応性比について最近報告している(16)。この報告にお いても，PE に対するスチレンーアクリロニトリル，ス チレンーアクリル酸メチル, あるいはメタクリル酸メチ ルーアクリル酸メチルの共グラフト系では, われわれの 結果と一致する結果を得ている。したがって，PE と 2 成分モノマーの系では，モノマーの極性などの差はあっ ても一方のモノマーがグラフト鎖の生長領域にとくに選 択的に浸透あるいは吸着されるというような特異現象は 起こらないものと考えられる。

一方，メタノール中での反応で得たグラフト重合体の グラフト鎖のモノマー単位組成は，Vc が計算值よりや や小さい傾向がある。本実験データだけでは結論は得ら れないが，ポリマー，溶媒間の不均一性，あるいは溶媒 の効果によるモノマーの浸透性の変化のために, モノマ 一の反応性比が変化する可能性はあり得る。メタノール 溶液系の場合, グラフト亱 $\left(G_{a}\right)$ がたかだか $22 \%$ と低く 分析結果に誤差を含む可能性もある。溶媒系の共グラフ 卜重合の共重合性に関する挙動についてはさらに検討す る必要がある。

\section{5. 結言}

ポリエチレンーVc, VAc 共グラフト重合体から末反応 ポリエチレンを抽出し, 純粋なグラフトポリエチレンを
取り出し，そのグラフト率 $\left(G_{n}\right)$ と反応に使われたポリ エチレン量 (RPE) を测定し，反応条件との関連で考察 した。その結果をまとめる。

i) モノマー中の Vc 成分が多いと $G_{n}$ の増加率は大 きく， RPE も大きい。またグラフト鎖中のモノマー組 成は一般のラジカル共重合の $r_{\mathrm{Vc}}, r_{\mathrm{VAc}}$ で計算した組成 と一致した。

ii) $G_{n}$ 值は反応時間とともに増大し, RPE 飽和後も $G_{n}$ 值が増大する傾向があることから，一般の均一系重 合とは異なり，停止の機会の少ない反応と考えられる。

iii) 反応温度が低い場合は $G_{n}$ の初期増加速度率は小 さいが，長時間にわたって反応が続く。反応温度が高く なると， $G_{n}$ の初期増加速度率は大きくなるが，短時間 で飽和するようになる。反応温度に対して， RPE 值も $G_{n}$ と同様な傾向を示す。ラジカルの移動と再結合に関 係すると考えられる。

RPE 值はたかだか $30 \%$ であ， RPE 值から計算した $G$ 值は約 3 であり, 他の方法で測定した值とほぼ一致す る。

iv） $75 \%$ のタノールを系に加えたメタノール溶液系 では RPE の経時変化には差が認められないが， $G_{n}$ はバ ルク系の約 $1 / 5$ 程度となる。メタノールによるモノマーの 希釈効果あるいはメタノールへの連鎖移動と考えられ る。

以上のように，反応条件を変えるとグラフト重合体を 構成する各組成をある程度設計することができることが わかった。

付 記 本報告の一部は第 20 回高分子叶論会（東京， 1971）で発表した。

\section{文献}

1) A. Chapiro: J. Polym. Sci., 23, 337 (1957)

2) A. W. Myers, C. E. Rogers, V. Stannett, M. Szwarc, G. R. Patterson, Jr., A. S. Hoffman, E. W. Merrill: J. Appl. Polym. Sci., 4, 159 (1960)

3) L. G. Amderson, D. A. Roper, J. K. Rieke: J. Polym. Sci., 43, 423 (1960)

4) W. J. Burlant, A. S. Hoffman: "Block and Graft Polymers", Reinhold, New York, p. 137 (1960)

5) D. S. Ballantine, A. Glines, D. J. Metz, J. Behr, R. B. Mesrobian, A. J. Rwstaino: J. Polym. Sci., 19, 219 (1956)

6) S. Machi, J. Silverman: J. Polym. Sci. A-1, 8, 3529 (1970)

7) 上田二士，門永政雄 : 高分子化学, 23，165 (1966)

8) V. Stannett, J. D. Wellons, H. Yasuda: J. Polym. Sci. C, 4, 551 (1963)

高分子化学, Vol. 30, No. 341 (Sept., 1973) 
高分子化学 (Kobunshi Kagaku), Vol. 30, No. 341, pp. 541-545 (Sept., 1973)

9) I. Sakurada, Y. Ikada, F. Horii: Makromol. Chem., 139, 171 (1970)

10) R. Hart, G. Smets: J. Polym. Sci., 5, 55 (1950)

11) D. V. Turner: Makromol. Reviews, 5, 299 (1971)

12）筏 義人, 堀井文敬, 西崎靖子, 前田一夫, 河原共栄, 桜田一郎：第 21 回高分子討論会要旨 集 1107 (1972, 京都)

13）高松俊昭, 古永捷慶, 深田栄一：高分子化学,
24, 795 (1967)

14) D. C. Waterman, M. Dole: J. Phys. Chem., 74, 1913 (1970)

15）岡田 実, 荒梆夫, 木原仁博，佐々木 隆， 貴家恒男, 関口秋雄 : 第 10 回放射線化学討論会 講演（広島, 1967 年)

16) G. Odian, R. L. Kruse, J. H. T. Kho: J. Polym. Sci. A-1, 9, 91 (1971)

数種のポリマーの存在下におけるラジカル重合により得られた

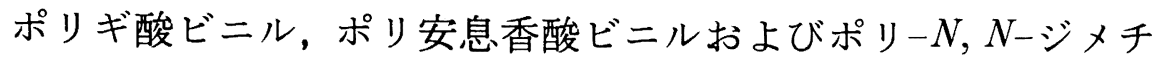
ルアクリルアミドの立体規則性

（受付1973年 3 月17日・掲载決定1973年 5 月21日）

坂口康義 ${ }^{* 1} \cdot$ 真山秀孝*1 $・$ 玉置克之*1 ・西野 潤*i

\begin{abstract}
要 旨 ギ酸ビニル(A), 安息香酸ビニル(B), および $N, N$-ジメチルアクリルアミド(C)をラジカル 開始刜を用いて，数種のポリマーの存在下で（モノマー $\mathrm{m} l$ あたり $0.5 \mathrm{~g}$ ) 重合させた。共存ポリマ 一による立体規制効果の順序は $\mathrm{B}>$ 酢酸ビニル>Aであり，それゆえよりかさ高い側鎖をもつビ ニルエステルは，共存ポリマーによってょり大きい立体規制効果を受けると考えられる。Gはアク リル酸メチル(D)に比べて，ポリ-D D たはポリエチレンオキシド(E)によってより大きい立体規制効 果を受ける。CとポリーD または E との間の強い相互作用が，この立体規制において重要な役割を 演じていると考えられる。
\end{abstract}

\section{1. 緒言}

既報において，メタクリル酸，メタクリル酸メチル， アクリル酸 $(\mathrm{AA})$ ，アクリル酸メチル $(\mathrm{MA})$ および酢酸 ビニル (VAc) を, 各種のビニル系ポリマーが溶液状で 高濃度に共存する状態でラジカル重合させ，共存ポリマ 一の構造と生成ポリマーの立体規則性規制効果との関倸 に主眼を置いて，検討を行なっている1) 3)。

本報では，同一系列のビニルモノマーの重合の際に， その側鎖構造によって共存ポリマーの立体規制効果がど のように変化するか在知ることに主眼を㯰いて，ビニル エステルであるギ酸ビニル $(\mathrm{VF})$ および安息香酸ビニル (VBz) を, 数種の共通のポリマーの共存下でラジカル重 合し，生成ポリマーの立体規則性を相互に，また既報の VAc ポリマーのそれと比較考察した。ポリマー不在下 でラジカル重合された PVF, PVBz, PVAc の立体規則性

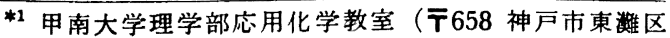
本山町岡本)
}

はほぼ同じである アクリルアミド (DMAAm) を数種のポリマーの共存下 でラジカル重合し，生成ポリマーの立体規則性を，同じ くアクリルモノマーである MA のポリマーのそれと比 較した。ポリマー不在下でラジカル重合された PDMA Am と PMA の立体規則性は，ほぼ同じである゙)。

\section{2. 実験および結果}

\section{1 モノマーおよび共存ポリマー}

$\mathrm{VF}, \mathrm{VBz}$ は既報と同様に，VAc とギ酸または安息香 酸とのエステル交換反応により合成した ${ }^{4), 5) 。 D M A A m ~}$ は既報と同様に，塩化アクリルとジメチルアミンとの反 応により合成した6)。

共存ポリマーとしては, 既報と同様のものを用いた1) 3)。すなわち, ポリビニルピロリドン (PVP), ポリアク リル酸メチル (PMA), ポリスチレン (PSt), ポリメタク

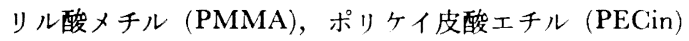
は普通のラジカル溶液重合物, ポリフマル酸ジェチル $(\mathbf{P}$ 